
ISSN : 2615-1995, E-ISSN : 2615-0654

J. Madani., Vol. 2, No. 1, Maret 2019 (175 - 184)

(C)2018 Lembaga Kajian Demokrasi

MADANI

dan Pemberdayaan Masyarakat (LKD-PM)

\title{
PERBANDINGAN KINERJA INVESTASI SAHAM SYARIAH DAN KONVENSIONAL DALAM MENENTUKAN KEBIJAKAN INVESTASI
}

\author{
Churniawansyah Sih Sumarmo \\ Fakultas Ekonomi dan Bisnis, Universitas Pancasila \\ churniawansyah@gmail.com \\ Suyanto \\ Fakultas Ekonomi dan Bisnis, Universitas Pancasila \\ Muhammad Yusuf \\ Fakultas Ekonomi dan Bisnis, Universitas Pancasila
}

\begin{abstract}
Abstrak
Penelitian ini bertujuan untuk menguji apakah lebih menguntungkan berinvestasi di saham Syariah atau konvensional. Metode penelitian adalah kuantitatif dengan uji metode indeks Sharpe, Treynor, dan AlphaJensen untuk menentukan yang memberikan tingkat keuntungan lebih baik. Peneliti mengambil sampel dari saham di indeks JII sebagai perwakilan saham Syariah dan saham dari indeks LQ45 sebagai perwakilan dari saham Konvensional. Untuk rentang tahun yang diambil adalah tahun 2014-2015, namun selain menghitung dari 2 tahun tersebut, peneliti juga meneliti per tahun untuk tahun 2014 dan 2015. Pada tahun 2014 dapat di asumsikan sebagai tahun yang baik untuk berinvestasi karena nilai-nilai makro ekonomi menunjukkan hasil yang positif. Tahun 2015 diasumsikan sebagai tahun resesi dimana nilai-nilai dari makro ekonomi menunjukkan nilai yang tidak sesuai harapan. Untuk tahun 2014, menunjukkan berinvestasi di LQ45 lebih menguntungkan dibandingkan di JII. Hal ini dibuktikan dimana ketiga indeks tersebut, Sharpe, Treynor, dan Alpha Jensen menunjukkan nilai yang lebih baik dibandingkan JII. Sedang untuk tahun 2015, berinvestasi di JII lebih menguntungkan karena saham-saham Syariah lebih kuat dalam menghadapi resesi/krisis ekonomi. Hal ini didukung dengan pengujian menggunakan indeks Sharpe, Treynor, dan Alpha-Jensen yang menunjukkan saham-saham JII lebih tinggi dibandingkan LQ45 pada tahun 2015. Untuk penghitungan 2 tahun berturutturut hasilnya bervariasi, dimana penghitungan Sharpe dan Alpha Jensen menunjukkan lebih baik berinvestasi di saham LQ45, sedang penghitungan Treynor menunjukkan lebih baik berinvestasi di saham JII.
\end{abstract}

Kata Kunci : JII, LQ 45, Indeks Sharpe, Indeks Treynor, Indeks Alpha Jensen

\begin{abstract}
Aims of this study is to test whether its more profitable to invest in sharia stocks or conventional stocks. The researchers will test the hypothesis by using Sharpe index, Treynor index, and Alpha Jensen index to determine which ones provide better stock profitability. Researchers took samples from JII (Jakarta Islamic Index) as a representatives of Sharia stock and LQ45 stocks as representatives of conventional stocks. We take sample period from 2014 to 2015, but researchers also test the hypothesis individually per year for 2014 and for 2015. This is done because year 2014 can be assumed as a good year to invest since the macroeconomic value shows a positive result. And for the year 2015, we can assume as year of recession because the values of the macroeconomic shows that is not good as expected. The results vary from all 3 index calculation. For 2014, where macroeconomic have good value, it indicates that investing in LQ45 is more profitable than in JII. It shows on all three indexes (Sharpe, Treynor, and Alpha Jensen) where LQ 45 have higher value than JII. While for the year 2015, where the market is experiencing a recession, Investing in JII is more profitable because Shariah stocks are stronger when facing economic recession/crisis. It is supported by the result of the Sharpe, Treynor, and Alpha Jensen indexes that show JII stock have higher value than LQ45 in 2015. While for 2 consecutive years, the results are vary, Sharpe and Alpha Jensen's index calculations show better investment in LQ45 stock, while Treynor's index shows better investing in JII shares.
\end{abstract}


Keywords : JII, LQ 45, Sharpe Index, Treynor Index, Alpha Jensen Index

\section{PENDAHULUAN}

\section{Latar Belakang}

Saat ini di Indonesia sudah mulai berkembang instrumen keuangan berbasis syariah seperti Bank Syariah, Pasar Modal Syariah, dan Pasar Komoditi Syariah. Pada saat krisis global melanda Amerika dan Eropa fakta dilapangan menunjukkan perekonomian dan keuangan yang berbasis syariah terbukti mampu bertahan dan dinilai ramah secara sosial dan juga memiliki etika serta lebih berpihak pada golongan menengah ke bawah.

Perkembangan pasar modal, khususnya pasar modal syariah Indonesia mengalami peningkatan yang signifikan dari tahun ke tahun. Kenaikan ini selain dari sisi kapitalisasi pasar namun juga dari jumlah investornya. Di tahun 2015 jumlah investor syariah mengalami peningkatan sebesar 20\% dari 2.795 investor menjadi 4.908 investor. Pada rentang waktu 2010-2014 kapitalisasi pasar modal syariah Indonesia naik signifikan. Pertumbuhan per saham syariah rata-rata $14,7 \%$, reksa dana syariah $21,6 \%$, sukuk korporasi $4,3 \%$, dan sukuk negara $48,3 \%$.

Pasar modal syariah saat ini sedang mengalami berkembang dengan pesat. Dana yang dimiliki oleh umat Islam atau pelaku pasar muslim di bursa efek di seluruh dunia mencapai 1,6 triliun dolar AS, dengan tingkat pertumbuhan rata-rata $17.3 \%$ pertahun. Walaupun terlihat besar namun jika dibandingkan dengan kapitalisasi pasar keuangan konvensional hal tersebut hanya $1 \%$ nya, pasar keuangan global sendiri memiliki kapitalisasi pasar sebesar 127 trilliun dolar. (MIFC, 2014).

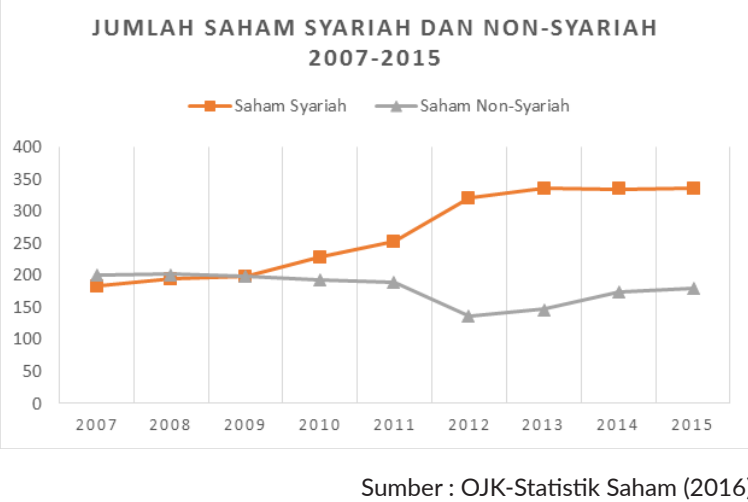

Penelitian ini bertujuan untuk membandingkan antara Kinerja saham-saham syariah dengan saham-saham Konvensional. Saham-saham Syariah di proxy-kan dengan Index JII dan Sahamsaham Konvensional di Proxy-kan dengan index LQ45. Komparasi dilakukan untuk membuktikan apakah kinerja saham-saham syariah lebih baik dibandingkan saham konvensional.

Penelitian yang telah dilakukan oleh Rachmayanti (2003) mengenai studi perbandingan kinerja portofolio saham syariah terhadap saham konvensional. Hasilnya saham syariah secara keseluruhan relatif lebih baik dari saham konvensional dari indeks kinerja yang ada. Beik et.al (2011) melakukan penelitian mengenai pasar modal syariah dan krisis keuangan global mendapatkan kesimpulan bahwa pasar modal syariah memiliki kemampuan yang lebih baik untuk kembali ke keadaan normal setelah adanya krisis. Hussein (2005) dengan penelitian berjudul Islamic Investment: Evidence From Dow Jones and FTSE Indices berdasarkan hasil penelitiannya menyebutkan bahwa Selama keseluruhan waktu pengamatan, indeks syariah menunjukkan kinerja yang lebih baik dari konvensional tetapi underperform saat periode bear.

Penelitian yang dilakukan Rahmawati (2013) menunjukkan Perbandingan kinerja dalam keseluruhan periode pengamatan, LQ-45 lebih baik kinerjanya dari JII, namun pengujian Independent Samples T test menunjukkan bahwa kinerja keduanya tidak berbeda secara signifikan. Pengukuran kinerja dengan Indeks Sharpe, Indeks Treynor, dan Indeks Alpha Jensen menunjukkan kinerja JII lebih baik dari LQ-45 pada periode keseluruhan pengamatan dan sebelum krisis. Sementara LQ-45 lebih baik dari JII pada periode setelah krisis; Antara IHSG dan indeks LQ-45 terdapat hubungan jangka panjang dan jangka pendek tetapi tidak untuk JII

Penelitian yang dilakukan Syafrida (2014) berdasarkan hasil yang didapat menunjukkan bahwa kinerja JII dengan kinerja LQ-45 tidak terdapat perbedaan yang signifikan, demikian pula antara kinerja reksadana syariah dengan kinerja reksadana konvensional. Hal ini menunjukkan bahwa instrumen berbasis syariah tidak kalah menguntungkan jika dibanding dengan instrumen berbasis konvensional. Bahkan jika diamati lebih cermat selama periode pengamatan terlihat kinerja reksadana syariah sedikit lebih baik daripada kinerja reksadana konvensional. Untuk itu bagi investor yang menginginkan cara berinvestasi sesuai prinsip Islam yaitu menghindari produk dan transaksi haram, bathil, maisyir, gharar, dan ribasaat ini tidak perlu ragu. Investor tersebut dapat menempatkan dananya pada instrumen pasar modal berbasis syariah, seperti saham syariah, sukuk, dan reksadana syariah, karena dijamin kehalalan produknya dan memiliki imbal hasil yang tidak kalah dari instrumen konvensional

Hasil penelitian serupa juga dilakukan oleh Hanafi (2012) penelitian ini mencoba memban- 
dingkan kinerja saham syariah (etis) dengan saham konvensional. Saham syariah diwakili oleh indeks JII (Jakarta Islamic Index), sedangkan saham konvensional diwakli oleh indeks LQ45. Hasil analisis menunjukkan bahwa tidak ada perbedaan kinerja yang signifikan antara dua indeks tersebut. Hasil ini menunjukkan bahwa investasi syariah layak dilakukan karena bisa memenuhi tujuan etis tanpa harus mengorbankan tujuan ekonomis.

Penelitian yang dilakukan Noviastuty (2011) Menunjukkan hasil perbandingan kinerja portofolio optimal antara portofolio optimal yang terbentuk berdasarkan saham tergolong indeks Kompas 100, Indeks LQ 45 dan Jakarta Islamics Indeks (JII) menunjukkan hasil bahwa kinerja portofolio optimal saham JII tidak lebih baik dari Kompas 100 dan LQ45. Hasil penelitian sejenis menyebutkan dari hasil analisa data didapatkan bahwa tidak ada perbedaan antara kinerja portofolio optimal saham JII dengan saham non-JII baik dilihat dari indeks Sharpe, Treynor maupun Jensen. Hal ini ditunjukkan dengan nilai $t_{\text {hitung }}$ yang tidak signifikan. Selain itu, kinerja portofolio optimal saham JII tidak lebih baik daripada saham non-JII yang ditunjukkan dengan nilai $\mathrm{t}_{\text {hitung }}$ yang tidak signifikan (Nuraini, 2010).

Penelitian yang dilakukan oleh Desdiana (2003) Dari ketiga metode pengukuran kinerja reksa dana yaitu metode Sharpe, Treynor, dan Jensen yang digunakan dalam penelitian ini diperoleh hasil bahwa kinerja reksa dana saham konvensional lebih baik (outperform) dibandingkan dengan reksa dana saham syariah. Kinerja reksa dana selama periode penelitian sangatlah dipengaruhi oleh kinerja pasar, dan juga tingkat suku bunga bebas risiko. Selain itu, volume perdagangan dan kondisi pasar juga mempengaruhi kinerja dari masing-masing reksa dana. Adanya prinsip pokok yang membedakan Reksa Dana Syariah dalam mengelola portfolio investasinya, sehingga menjadi berbeda dari Reksa Dana Konvensional. Di Indonesia jumlah saham syariah yang beredar terbatas dibandingkan dengan Reksa Dana Saham Konvensional. Reksa Dana syariah tidak hanya mempertimbangkan return atau tingkat pengembalian dari investasinya semata, namun juga mempertimbangkan kehalalan dari instrumen yang akan dibelinya, yaitu bukan merupakan instrumen yang menghasilkan riba. Selain itu, risiko saham syariah mengandung ketidakpastian yang relatif lebih kecil dibandingkan dengan saham konvensional.

Penelitian yang dilakukan Medhioub dan Chffai (2016) pada tahun-tahun krisis 2008, 2009, dan 2011 menunjukkan bahwa saham syariah lebih efesien dalam menghadapi krisis yang terjadi dibandingkan saham konvensional. Selanjutnya dalam penelitian tersebut Medhioub dan Chffai (2016) melihat adanya korelasi cross sectional stock market antara indeks Syariah dan konvensional dan terdapat kemiripan antara saham-saham Syariah dan saham-saham konvensional.

Dalam penelitiannya Farooq dan Zaheer (2011) menggunakan data rinci tentang neraca bank dan pinjaman yang diberikan dari pemerintah Pakistasn selama tahun 2008, untuk memeriksa apakah terdapat perbedaan perilaku bank syariah dan bank konvensional selama kepanikan finansial yang terjadi selama September-Oktober 2008. Hasilnya menunjukkan bahwa bank yang memiliki cabang bank syariah kurang rentan terhadap risiko penarikan deposit saat terjadi kepanikan. Hal ini menunjukkan bahwa bank syariah memiliki ketahanan dalam menghadapi krisis.

\section{Pembatasan Masalah}

Berdasarkan pertimbangan waktu dan tenaga serta supaya penelitian dapat dilakukan lebih fokus maka tidak semua masalah akan di teliti. Oleh karena itu, penelitian ini dibatasi oleh hal-hal berikut:

a. Sampel yang akan diteliti adalah perusahaanperusahaan yang terdaftar di Bursa Efek Indonesia (BEI), aktif melakukan transaksi serta menerbitkan laporan keuangan tahunan dalam periode penelitian.

b. Periode penelitian adalah Januari 2014-Desember 2015.

c. Metode penilaian menggunakan Sharpe Index, Treynor Index, dan Alpha-Jensen Index.

\section{METODE}

\section{Kajian Teori}

Berbicara tentang investasi di pasar modal tidak lepas dari dua hal yaitu keuntungan atau sering disebut return dan risiko untuk mendapat kerugian atau risk. Dalam penelitian ini, penulis hanya memperhitungkan return realisasi saham yang berasal dari capital gain tanpa memperhitungkan dividen yield. Return yang digunakan dalam penelitian ini adalah return realisasi atau sering disebut actual return. Actual return (tanpa dividen yield) dapat dihitung dengan rumus (Hartono, 2010); (Hussein, 2005)

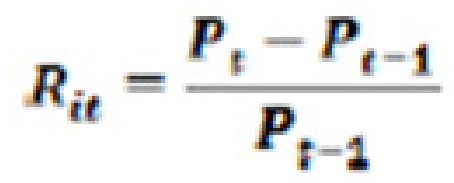

Rit : Return Saham pada hari t

$\mathrm{P}_{\mathrm{t}} \quad$ : Harga Saham pada hari $t$

$\mathrm{P}_{\mathrm{t}-1}^{\mathrm{t}}$ : Harga Saham pada hari sebelum $\mathrm{t}$ 
Sehubungan dengan risiko, risiko mengacu pada penyimpangan suatu variabel. Standar deviasi $(\sigma)$ adalah ukuran statistik mengenai variabilitas atau penyimpangan dari serangkaian hasil observasi. Menurut Hartono (2010), risiko sering dihubungkan dengan penyimpangan atau deviasi dari keuntungan yang diterima dengan yang diekspektasikan. Untuk menghitung risiko, metode yang banyak digunakan adalah deviasi standar yang mengukur absolut penyimpangan nilai-nilai yang sudah terjadi dengan nilai ekspektasinya.

$$
S D=\sqrt{\frac{\sum_{i=1}^{n}[X i-E(X i)]^{2}}{n-1}}
$$

Dimana:

SD : Standar Deviasi

$\mathrm{E}(\mathrm{Xi})$ : Nilai ekspektasi

$\mathrm{Xi}$ : Nilai ke-i

Zubir (2011) menyatakan terdapat empat parameter yang bisa digunakan sebagai ukuran kinerja saham, yaitu : (1) Rasio excess return terhadap standar deviasi (sharpe measure); (2) Differential return dengan deviasi standar sebagai risiko; (3) Rasio excess return terhadap beta (treynor measure); (4) Jensen differential performance index. Treynor Index didefinisikan sebagai risiko premium per unit dari risiko sistematis, dimana risiko sistematis diukur dalam bentuk beta saham. Secara matematis Treynor Indeks dirumuskan :

$$
T I=\frac{\overline{R_{t}}-\overline{R_{f}}}{\beta_{t}}
$$

Dimana:

$\mathrm{R}_{t}$ : Rata-rata return saham atau indeks

$\mathrm{R}_{\mathrm{f}}$ : Rata-rata return bebas risiko

$B_{i}$ : Beta Saham atau Indeks

William F. Sharpeditahun 1966menggunakan Sharpe Index dan menggunakan ukuran ini untuk mengevaluasi kinerja mutual fund. Sharpe Index adalah rasio excess return sebuah portofolio dari return terhadap simpangan baku. Secara matematis Sharpe index diformulasikan sebagai berikut :

$$
S R=\frac{\overline{R_{t}}-\overline{R_{f}}}{\sigma_{l}}
$$

\section{Dimana:}

$\mathrm{R}_{\mathrm{t}}$ : Rata-rata return saham atau indeks

$\mathrm{R}_{\mathrm{f}}$ : Rata-rata return bebas risiko

$\sigma_{\mathrm{i}} \quad$ : Deviasi Standar Return Saham atau Indeks
Jensen pada 1968 membuat model untuk mengevaluasi kinerja portofolio yang didasarkan pada Capital Aset Pricing Model (CAPM). Model pengukuran kinerja Jensen bertujuan untuk mengukur perbedaan risiko premium portofolio (portfolio risk premium) dari risiko premium pasar (market risk premium) pada tingkat beta portofolio tertentu. Pengukuran Jensen dirumuskan sebagai berikut :$$
\alpha=\overline{R_{\imath}}-\left[\overline{\boldsymbol{R}_{f}}+\boldsymbol{\beta}_{i}\left(\overline{\boldsymbol{R}_{m}}-\overline{\boldsymbol{R}_{f}}\right)\right]
$$

Dimana:

$\mathrm{R}_{\mathrm{t}}$ : Rata-rata return saham atau indeks

$\mathrm{R}_{\mathrm{f}}$ : Rata-rata return bebas risiko

$\mathrm{R}_{\mathrm{m}}$ : Rata-rata return pasar

$\mathrm{B}_{\mathrm{i}}^{\mathrm{m}}$ : Beta Saham atau Indeks

\section{Populasi dan Sampel}

Metode pemilihan sampel penelitian adalah dengan metode purposive judgment sampling, yaitu pemilihan sampel berdasarkan kriteria yang telah dirumuskan terlebih dahulu oleh peneliti. Berikut kriteria Sampel yang digunakan dalam penelitian dan jumlah sampel setelah penarikan sampel:

\begin{tabular}{|c|l|c|c|}
\hline \multicolumn{4}{|c|}{ Tabel Kriteria Sampel } \\
\hline No & \multicolumn{1}{|c|}{ Kriteria Sampel } & JII & LQ45 \\
\hline 1 & $\begin{array}{l}\text { Sampel harus berada dalam indeks JII dan } \\
\text { LQ45 pada tahun 2014-2015. }\end{array}$ & 39 & 61 \\
\hline 2 & $\begin{array}{l}\text { Sampel harus secara berturut-turut dari } \\
\text { tahun 2014-2015. }\end{array}$ & 21 & 31 \\
\hline 3 & $\begin{array}{l}\text { Tidak boleh ada sampel yang sama antara } \\
\text { kedua indeks tersebut. }\end{array}$ & 5 & 5 \\
\hline 4 & $\begin{array}{l}\text { Lima saham terbesar berdasar nilai pasar } \\
\text { diambil masing-masing dari indeks Jll dan } \\
\text { LQ45. }\end{array}$ & 5 & 5 \\
\hline
\end{tabular}

Berikut saham-saham yang sudah sesuai dengan kriteria sampel kami: Sampel saham untuk Indeks LQ45, diurutkan berdasarkan nilai kapitalisasi

1. Bank BCA (kode saham: BBCA)

2. Bank BRI (kode saham: BBRI)

3. Bank Mandiri (kode saham: BMRI)

4. PT Gudang Garang (kode saham: GGMR)

5. Bank BNI (kode saham: BBNI)

Sampel saham untuk Indeks JII, diurutkan berdasarkan nilai kapitalisasi

1. PT Unilever Indonesia (kode saham: UNVR)

2. PT Telekomunikasi Indonesia (kode saham: TLKM)

3. PT Astra International (kode saham: ASII)

4. PT Perusahaan Gas Negara (kode saham: PGAS)

5. PT Kalbe farma (kode saham: KLBF) 


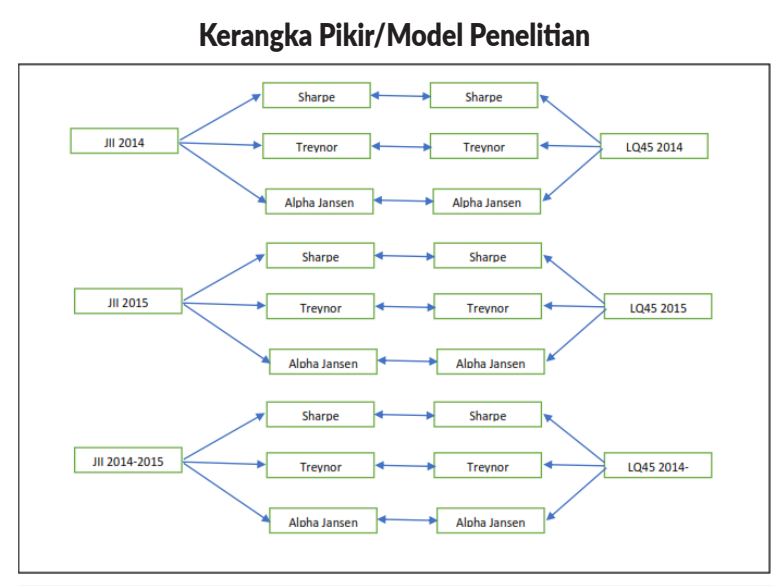

\begin{tabular}{|c|c|c|c|}
\hline \multicolumn{4}{|c|}{ Operasionalisasi Variabel } \\
\hline Variabel & Dimensi & Indikator & Skala Ukur \\
\hline \multirow{2}{*}{$\begin{array}{l}\text { Return Saham } \\
\text { Syariah }\end{array}$} & Definisi & $\begin{array}{l}\text { Tingkat pengembalian dari saham- } \\
\text { saham yang memenuhi nilai-nilai } \\
\text { syariah }\end{array}$ & \multirow{2}{*}{ Rasio } \\
\hline & Penilaian & $R_{i t}=\frac{P_{t}-P_{t-1}}{P_{t-1}}$ & \\
\hline \multirow{2}{*}{$\begin{array}{l}\text { Return Saham } \\
\text { Konvensional }\end{array}$} & Definisi & $\begin{array}{l}\text { Tingkat pengembalian dari saham- } \\
\text { saham yang tidak memenuhi } \\
\text { nilai-nilai syariah }\end{array}$ & \multirow{2}{*}{ Rasio } \\
\hline & Penilaian & $R_{i t}=\frac{P_{t}-P_{t-1}}{P_{t-1}}$ & \\
\hline \multirow{2}{*}{ Indeks Sharpe } & Definisi & $\begin{array}{l}\text { Rasio excess return sebuah } \\
\text { portofolio dari return terhadap } \\
\text { simpangan baku }\end{array}$ & \multirow{2}{*}{ Rasio } \\
\hline & Penilaian & $S R=\frac{\overline{R_{t}}-\overline{R_{f}}}{\sigma_{i}}$ & \\
\hline \multirow{2}{*}{$\begin{array}{l}\text { Indeks } \\
\text { Treynor }\end{array}$} & Definisi & $\begin{array}{l}\text { risiko premium per unit dari } \\
\text { risiko sistematis, dimana risiko } \\
\text { sistematis diukur dalam bentuk } \\
\text { beta saham }\end{array}$ & \multirow[t]{2}{*}{ Rasio } \\
\hline & Penilaian & $T I=\frac{\overline{\boldsymbol{R}_{t}}-\overline{\boldsymbol{R}_{f}}}{\boldsymbol{\beta}_{l}}$ & \\
\hline \multirow[t]{2}{*}{$\begin{array}{l}\text { Indeks Alpha } \\
\text { Jensen }\end{array}$} & Definisi & $\begin{array}{l}\text { Model pengukuran kinerja Jensen } \\
\text { bertujuan untuk mengukur } \\
\text { perbedaan risiko premium } \\
\text { portofolio (portfolio risk premium) } \\
\text { dari risiko premium pasar (market } \\
\text { risk premium) pada tingkat beta } \\
\text { portofolio tertentu }\end{array}$ & \multirow[t]{2}{*}{ Rasio } \\
\hline & Penilaian & $\alpha=\overline{R_{t}}-\left[\overline{R_{f}}+\beta_{i}\left(\overline{R_{m}}-\overline{R_{f}}\right)\right]$ & \\
\hline
\end{tabular}

Teori Sharpe (1966) menggunakan Sharpe Index dan menggunakan ukuran ini untuk mengevaluasi kinerja mutual fund. Sharpe Index adalah rasio excess return sebuah portofolio dari return terhadap simpangan baku. Penelitian yang dilakukan oleh Abeity \& Ahmad (2008) menunjukkan bahwa tidak ada perbedaan yang signifikan antara kinerja saham Syariah dan Nonsyariah. Dari penelitian tersebut maka hipotesis pada penelitian ini adalah:

$\mathrm{H}_{1}$ : Indeks LQ45 mempunyai kinerja yang tidak lebih baik dibandingkan Jakarta Islamic Index dengan metode Sharpe pada tahun 2014-2015.

$\mathrm{H}_{2}$ : Indeks LQ45 mempunyai kinerja yang tidak lebih baik dibandingkan Jakarta Islamic Index dengan metode Treynor pada tahun 2014-2015

$\mathrm{H}_{3}$ : Indeks LQ45 mempunyai kinerja yang tidak lebih baik dibandingkan Jakarta Islamic Index dengan metode Jensen pada tahun 2014-2015

\section{HASIL dan PEMBAHASAN}

Hasil

Tabel Statistik Deskriptif

JII, LQ45, IHSG Tahun 2014, 2015, 2014-2015

\begin{tabular}{|l|r|c|c|c|c|}
\hline & \multicolumn{1}{|c|}{ N } & Minimum & Maximum & Mean & Std. Deviation \\
\hline JII-(2014) & 53 & -0.07 & 0.09 & 0.0042 & 0.02448 \\
\hline JII-(2015) & 51 & -0.07 & 0.09 & 0.0003 & 0.03265 \\
\hline JII-(2014-2015) & 104 & -0.07 & 0.09 & 0.0023 & 0.02870 \\
\hline LQ45-(2014) & 53 & -0.07 & 0.08 & 0.0073 & 0.02763 \\
\hline LQ45-(2015) & 51 & -0.09 & 0.08 & -0.0010 & 0.03530 \\
\hline LQ45-(2014-2015) & 104 & -0.09 & 0.08 & 0.0032 & 0.03175 \\
\hline IHSG-(2014) & 53 & -0.06 & 0.05 & 0.0040 & 0.01901 \\
\hline IHSG-(2015) & 51 & -0.06 & 0.09 & 0.0022 & 0.02507 \\
\hline IHSG-(2014-2015) & 104 & -0.06 & 0.09 & 0.0010 & 0.02230 \\
\hline
\end{tabular}

Pengujian Normalitas data menggunakan one-sample Kolmogorov-Smirnov dengan tingkat signifikansi 5\%. Sesuai dengan hasil yang didapat menggunakan software SPSS menunjukkan bahwa nilai Kolmogorov-Smirnov Z untuk JII adalah sebesar 0,634; sedangkan untuk index LQ45 adalah 0,462 dan untuk IHSG adalah 0,981; karena nilai hitung untuk ke-tiga indeks tersebut dibawah 1,97 maka disimpulkan bahwa data terdistribusi normal.

\begin{tabular}{|l|c|r|r|}
\hline \multicolumn{4}{|c|}{ One Sample Kolmogorov-Smirnov Test } \\
\hline \multirow{2}{|c|}{} & $\begin{array}{c}\text { Unstandardized } \\
\text { Residual }\end{array}$ & $\begin{array}{c}\text { Unstandardized } \\
\text { Residual }\end{array}$ \\
\hline $\mathrm{N}$ & Mean & 104 & 104 \\
\hline $\begin{array}{l}\text { Normal } \\
\text { Parameters }\end{array}$ & Std. Deviation & .0000000 & .0000000 \\
\hline $\begin{array}{l}\text { Most Extreme } \\
\text { Differences }\end{array}$ & Absolute & .075 & .02279799 \\
\cline { 2 - 4 } & Positive & .059 & .070 \\
\cline { 2 - 4 } & Negative & -.075 & -070 \\
\hline Kolmogrov-Smirnov Z & & .063 \\
\hline Asymp. Sig (2-tailed) & & .601 & .713 \\
\hline \multicolumn{2}{|l|}{} & Sumber: Hasil Olahan Peneliti (2018) \\
\hline
\end{tabular}

\begin{tabular}{|c|c|c|c|c|c|c|}
\hline \multicolumn{7}{|c|}{ Tabel Indeks Sharpe LQ45 dan JII } \\
\hline \multirow{2}{*}{ Keterangan } & \multicolumn{3}{|c|}{ LQ45 } & \multicolumn{3}{|c|}{ ЛII } \\
\hline & 2014 & 2015 & 2014-2015 & 2014 & 2015 & $2014-2015$ \\
\hline Rata-Rata return & $0.73 \%$ & $-0.10 \%$ & $0.32 \%$ & $0.42 \%$ & $0.03 \%$ & $0.23 \%$ \\
\hline Standard Deviasi & 0.02763 & 0.0353 & $3.18 \%$ & 0.0248 & 0.03265 & 0.028705068 \\
\hline Rata-rata SBI & $0.145 \%$ & $0.145 \%$ & $0.145 \%$ & $0.145 \%$ & $0.145 \%$ & $0.145 \%$ \\
\hline Indeks Sharpe & 0.2117 & -0.0704 & 0.0555 & 0.1107 & -0.0347 & 0.0294 \\
\hline \multicolumn{7}{|c|}{ Sumber: Hasil Olahan Peneliti (2018 } \\
\hline
\end{tabular}


Untuk tahun 2014, LQ45 resikonya lebih tinggi 1,1x dari risiko saham JII. Sedangkan dari sisi keuntungan, keuntungan yang di miliki LQ45 sebesar 1,7x dari keuntungan saham JII. Sehingga hal ini membuat berinvestasi saham di saham LQ45 lebih menarik karena keuntungan yang lebih tinggi.

Untuk tahun 2015, saham-saham JII masih bisa mendapatkan keuntungan dibandingkan saham-saham LQ45 yang mengalami kerugian. Dan hal ini juga di tambah oleh resiko di sahamsaham LQ45 lebih tinggi 1,08x dibanding saham-saham JII. Sehingga pada tahun 2015 lebih menguntungkan berinvestasi di saham JII menurut perhitungan Sharpe. Untuk jangka lebih Panjang, tahun 2014-2015, ternyata lebih menarik untuk berinvestasi di LQ45, karena walaupun risiko yang dihadapi menjadi lebih tinggi namun tingkat keuntungan juga lebih besar dibanding berinvestasi di saham JII.

Pertumbuhan ekonomi yang melemah di tahun 2015 dibanding tahun 2014, membuat berinvestasi pada bursa saham kurang menguntungkan untuk tahun 2015. Hal ini terlihat pada indeks Sharpe yang ke-duanya, baik JII dan LQ45, menunjukkan hasil yang negatif. Terlihat pada tahun 2015, menaruh saham pada bursa JII lebih menguntungkan karena resiko yang lebih sedikit dibandingkan LQ45. Memang saham-saham dari bursa JII lebih kuat dalam menghadapi risiko dibandingkan dengan saham LQ45. Hal ini dikarenakan, pada saham-saham JII lebih memiliki kepastian dalam proses bisnisnya. Contohnya, untuk saham-saham Perbankan, akan kesulitan mengeluarkan pendanaan jika terjadi perlambatan ekonomi.

Jika investor melakukan investasi selama 2 tahun berturut-turut, dari tahun 2014 sampai 2015, ternyata berinvestasi pada saham-saham LQ45 lebih menguntungkan. Semakin lama periode investasi akan semakin mengurangi tingkat resiko yang akan dihadapi. Hal ini dibuktikan pada penghitungan indeks Sharpe dimana, jika hanya pertahun 2015, maka akan lebih menguntungkan berinvestasi di saham-saham JII. Namun bila dilakukan penghitungan secara berturut-turut tenyata berinvestasi pada LQ45 lebih baik dibanding berinvestasi di JII. Pada penghitungan menggunakan indeks sharpe LQ45 menghasilkan nilai 0,0555 sedangkan indeks JII hanya menghasilkan nilai 0,0294

\begin{tabular}{|l|c|c|c|c|c|c|}
\hline \multicolumn{5}{|c|}{ Tabel Indeks Treynor LQ45 dan JII } \\
\cline { 2 - 7 } & \multicolumn{3}{|c|}{ LQ45 } & \multicolumn{3}{c|}{ JII } \\
\cline { 2 - 7 } Keterangan & 2014 & 2015 & $2014-2015$ & 2014 & 2015 & $2014-2015$ \\
\hline $\begin{array}{l}\text { Rata-Rata } \\
\text { return }\end{array}$ & $0.7299 \%$ & $-0.1040 \%$ & $0.3210 \%$ & $0.4194 \%$ & $0.0313 \%$ & $0.2291 \%$ \\
\hline $\begin{array}{l}\text { Standard } \\
\text { Deviasi }\end{array}$ & 0.0276 & 0.0353 & 0.0318 & 0.0248 & 0.0327 & 0.0287 \\
\hline
\end{tabular}

\begin{tabular}{|l|r|r|r|r|r|r|}
\hline Rata-rata SBI & $0.1450 \%$ & $0.1446 \%$ & $0.1448 \%$ & $0.1450 \%$ & $0.1446 \%$ & $0.1448 \%$ \\
\hline Rata-rata IHSG & $0.4018 \%$ & $-0.2186 \%$ & $0.0975 \%$ & $0.4018 \%$ & $-0.2186 \%$ & $0.0975 \%$ \\
\hline Beta Saham & 0.782 & 1.104 & 0.991 & 0.788 & 0.955 & 0.887 \\
\hline Indeks Treynor & 0.0335 & 0.0307 & 0.0306 & 0.0296 & 0.0327 & 0.0307 \\
\hline \multicolumn{7}{|c|}{ Sumber: Hasil Olahan Peneliti (2018) } \\
\hline
\end{tabular}

Untuk tahun 2014, penghitungan menggunakan Indeks Treynor pada LQ45 lebih besar dibandingkan indeks JII. Hal ini dikarenakan Beta saham yang lebih tinggi di indeks JII dibandingkan LQ45. Pada indeks LQ45 beta yang didapat adalah 0,782 lebih tinggi sedikit dibandingkan indeks JII sebesar 0,788. Sedang return LQ45 lebih tinggi $1,7 \mathrm{x}$ dibandingkan return JII. Hal ini membuat saham-saham JII lebih berfluktuasi dibandingkan saham-saham LQ45. Hasil ini sesuai dengan perhitungan menggunakan indeks Sharpe, dimana untuk tahun 2014 lebih menguntungkan berinvestasi di LQ45.

Pada tahun 2015, terjadi hal yang berkebalikan dengan tahun 2014, dimana beta saham indeks JII lebih rendah dibandingkan dengan indeks LQ45. Indeks LQ45 memiliki beta saham 1,104 sedangkan indeks JII menghasilkan beta saham hanya sebesar 0,955. Hal ini juga sesuai dengan perhitungan indeks Sharpe dimana untuk tahun 2015 lebih menguntungkan berinvestasi di saham JII.

Hal ini menandakan bahwa untuk tahun yang memiliki perekonomian yang kurang baik akan lebih bijak mengambil saham-saham JII karena saham-saham tersebut lebih kuat dalam menghadapi krisis ekonomi.

Untuk gabungan tahun 2014-2015, indek JII menghasilkan nilai yang lebih baik $(0,0307)$ dibandingkan indek LQ45 (0,0306). Salah satu penyebabnya adalah beta saham yang menurun menjadi 0,887 jika dilakukan penghitungan secara gabungan tahun 2014-2015. Walaupun, indek LQ45 juga terjadi penurunan beta menjadi 0,991 namun dengan standar deviasi yang lebih tinggi di LQ45, membuat berinvestasi di indeks JII lebih menguntungkan.

\begin{tabular}{|l|r|r|r|r|r|r|}
\hline \multirow{5}{*}{ Tabel Indeks Alpha Jehsen LQ45 dan JII } \\
\cline { 2 - 7 } & \multicolumn{3}{|c|}{ LQ45 } & \multicolumn{3}{c|}{ III } \\
\cline { 2 - 7 } & 2014 & 2015 & $2014-2015$ & 2014 & 2015 & $2014-2015$ \\
\hline $\begin{array}{l}\text { Rata-Rata } \\
\text { return }\end{array}$ & $0.73 \%$ & $-0.10 \%$ & $0.32 \%$ & $0.42 \%$ & $0.03 \%$ & $0.23 \%$ \\
\hline $\begin{array}{l}\text { Rata-rata } \\
\text { return pasar }\end{array}$ & $0.40 \%$ & $-0.22 \%$ & $0.10 \%$ & $0.40 \%$ & $-0.22 \%$ & $0.10 \%$ \\
\hline $\begin{array}{l}\text { Standard } \\
\text { Deviasi }\end{array}$ & 0.0276 & 0.0353 & 0.0318 & 0.0248 & 0.0327 & 0.0287 \\
\hline Rata-rata SBI & $0.14 \%$ & $0.14 \%$ & $0.14 \%$ & $0.14 \%$ & $0.14 \%$ & $0.14 \%$ \\
\hline Beta Saham & 0.782 & 1.104 & 0.991 & 0.788 & 0.955 & 0.887 \\
\hline $\begin{array}{l}\text { Indeks Alpha } \\
\text { jensen }\end{array}$ & 0.003841 & 0.001524 & 0.002230 & 0.000721 & 0.002335 & 0.001262 \\
\hline & & & \multicolumn{5}{c}{ Sumber: Hasil Olahan Peneliti (2018) } \\
\hline
\end{tabular}


Penghitungan dengan menggunakan indeks Apha Jensen menggunakan rata-rata return pasar sebagai bagiannya. Hal ini untuk menunjukkan bahwa pergerakan saham yang nantinya dipilih investor akan lebih baik dibanding dengan pergerakan pasar. Untuk tahun 2014, indeks LQ45 lebih baik dibandingkan dengan indeks JII dengan penghitungan metode indeks Alpha Jensen. Hal ini dikarenakan return LQ45 yang lebih tinggi $82,5 \%$ daripada keuntungan yang diperoleh pasar. Sementara itu, Indek JII hanya membukukan keuntungan lebih tinggi 5\% dibandingkan keuntungan yang diperoleh pasar.

Untuk tahun 2015, dengan menggunakan metode penghitungan Alpha Jensen, indek JII lebih baik dibandingkan dengan LQ45. Pada tahun ini, secara keseluruhan nilai pasar menurun dibandingkan tahun sebelumnya. Hal ini pun berimpak pada indeks LQ45. Secara keseluruhan pasar mengalami penurunan sebesar $0,22 \%$, sedangkan indeks LQ45 mengalami penurunan sebesar $0,10 \%$ atau $54,54 \%$ lebih rendah dari penurunan harga pasar. Sedangkan untuk indeks JII masih menciptakan keuntungan walaupun pasar sedang mengalami penurunan. Hal ini membuktikan indeks JII lebih kuat dalam menghadapi krisis dibandingkan indek LQ45. Indeks JII membukukan rata-rata keuntungan sebesar 0,03\% selama tahun 2015 .

Untuk gabungan tahun 2014-2015, Indeks LQ45 mencatatkan nilai lebih tinggi dibandingkan indeks JII. Hal ini dikarenakan return yang lebih tinggi dibandingkan indeks JII. Return pada indeks JII hanya sebesar $0,23 \%$, lebih rendah dengan return LQ45 yang sebesar 0,32\%. Walaupun standar deviasi pada indeks JII hanya sebesar 0,0287, lebih kecil dibandingkan standar deviasi rata-rata LQ45 yang sebesar 0,0318, namun dengan tingkat keuntungan yang lebih tinggi dibandingkan return yang akan didapat membuat berinvestasi pada indeks LQ45 lebih menguntungkan.

Dengan didukung data-data diatas maka, kita dapat menarik kesimpulan jika sektor perekonomian sedang membaik tingkat pengembalian di LQ45 lebih menguntungkan dibanding di JII. Perhitungan menggunakan indeks Sharpe, Treynor dan Alpha Jensen menunjukkan nilai yang didapat di LQ45 lebih tinggi dibandingkan JII pada tahun 2014.

Berbeda dengan tahun 2014, pada tahun 2015 ke-3 indeks perhitungan, Indeks Sharpe, Treynor, dan Alpha Jensen, menunjukkan nilai yang lebih tinggi dibandingkan pada indeks JII dibandingkan indeks LQ45. Hal ini menunjukkan bahwa pada perekonomian yang sedang menurun berinvestasi pada indek JII lebih menguntungkan dibandingkan indeks LQ45.
Untuk penghitungan gabungan tahun 20142015, hasil yang didapat lebih bervariasi dimana indeks Alpha Jensen dan Sharpe lebih tinggi pada indeks LQ45 namun pada indeks Treynor nilai lebih tinggi pada indeks JII. Pada penghitungan indeks alpha Jensen, selain memasukkan suku bunga bank Indonesia namun juga memasukan rata-rata return pasar sebagai perbandingan. Berdasarkan penghitungan Alpha Jensen, berinvestasi di indeks LQ45 kurang menguntungkan karena risiko yang lebih tinggi dibanding return yang didapat dibandingkan ratarata return pasar.

\section{Pembahasan}

Dari awal tahun 2014 sampai akhir tahun 2014, secara keseluruhan bursa bergerak naik secara bertahap. Terjadinya perlambatan pada Juni dan September lebih dikarenakan ada Pemilu DPR dan Presiden. Setelah itu, bursa IHSG meningkat kembali sampai puncaknya pada bulan Desember 2014 dimana bursa mencapai angka 5.166 atau naik sebesar 20,3\% dibanding tahun sebelumnya.

Sepanjang sejarah pasar modal Indonesia, tahun politik atau masa diadakannya pemilihan umum untuk memilih presiden selalu memberikan berkah para pelakunya. Bukti nyata dari hal itu adalah indeks yang selalu tercatat naik di tahun pemilu. Contohnya pada 2014, sejak awal tahun hingga Rabu (24/12), Indeks Harga Saham Gabungan (IHSG) telah menanjak 20,89 persen. Bahkan, jika dicermati lebih jauh ternyata sejak era reformasi, jika ada pemilu presiden dan DPR bursa akan meningkat secara signifikan. Pada akhir tahun 2004, bursa ditutup pada level $1.000,23$ dari tahun sebelumnya yang ditutup di level 704,49 atau terdapat kenaikan sebesar $44,56 \%$

Hal tersebut kembali terulang di tahun 2009. Di akhir tahun 2008 bursa ditutup pada level $1.355,40$, namun pada penutupan bursa tahun 2009 ternyata bursa meningkat signifikan sebesar $76,32 \%$, menjadikan bursa ditutup pada level 2.534,35 Sementara sepanjang 2009 atau tahun pemilu sebelumnya, IHSG juga mampu mencetak peningkatan yang cukup signifikan sebesar 76,32 persen. Adapun di akhir 2008 indeks berada pada level $1.355,40$, dan ditutup di posisi $2.534,35$ pada penghujung 2009.

Walaupun kenaikan yang terjadi pada tahun 2014 tidak sebesar pada tahun 2004 dan 2009, namun hal tersebut bisa menjadi sinyal positif bagi para investor untuk berinvestasi yang lebih besar pada tahun-tahun Pemilihan umum DRP dan Presiden. Lancarnya proses Pemilu membuat keyakinan investor bertambah akan berkembangnya ekonomi Indonesia kedepannya. 
Pertumbuhan ekonomi tahun 2014 sedikit melambat dibandingkan dengan tahun 2013. Pada tahun 2014 ekonomi bertumbuh sebesar 5,02\% dibandingkan dengan tahun sebelumnya sebesar 5,78\%.Beberapa hal yang menyebabkan perlambatan ekonomi adalah defisitnya neraca perdagangan dan pelemahan nilai rupiah terhadap dollar Amerika Serikat. Pelemahan dolar Amerika Serikat merupakan akibat dari The Fed meningkatkan suku bunga-nya. Hal ini tidak hanya berdampak pada Indonesia namun juga berdampak pada seluruh mata uang asing lainnya.

Jumlah perusahaan yang melakukan Initial Public Offering (IPO) juga menurun dibandingkan tahun 2014. Hal yang menyebabkannya adalah perusahaan-perusahaan menunggu stabilitas politik setelah Pemilu Presiden dan DPR.

Berdasarkan data PT Bursa Efek Indonesia (BEI), sepanjang 2014 terdapat 23 perusahaan yang melantai di bursa, atau turun 25,80 persen dari catatan 2013 sebanyak 31 emiten. Sementara, dari sisi nilai selama 2014, jumlah total dana yang diraup dari IPO mencapai Rp9,02 triliun, anjlok 46,14 persen dari perolehan sepanjang 2013 yang mencapai Rp16,747 triliun.

Adapun selama periode Januari-Desember 2014 terdapat 23 Perusahaan Tercatat baru di BEI, yakni PT Bank Panin Syariah Tbk (PNBS), PT Asuransi Mitra Maparya Tbk (ASMI), PT Bank Ina Perdana Tbk (BINA), PT Capitol Nusantara Indonesia Tbk (CANI).Selain itu adalah PT Bali Towerindo Sentra Tbk (BALI), PT Wijaya Karya Beton Tbk (WTON), PT Graha Layar Prima Tbk (BLTZ), PT Intermedia Capital Tbk (MDIA), PT Eka Sari Lorena Transport Tbk (LRNA), PT Dwi Aneka Jaya Kemasindo Tbk. (DAJK), PT Link Net Tbk (LINK), PT Chitose Internasional Tbk (CINT), PT Magna Finance Tbk. (MGNA), PT Batavia Prosperindo Internasional Tbk (BPII). Kemudian disusul PT Mitrabara Adiperdana Tbk (MBAP), PT Sitara Propertindo Tbk (TARA), PT Bank Dinar Indonesia Tbk (DNAR), PT Blue Bird Tbk (BIRD), PT Soechi Lines Tbk (SOCI), PT Impack Pratama Industri Tbk (IMPC), PT Intan Baruprana Finance Tbk (IBFN), PT Bank Agris Tbk (AGRS), dan PT Golden Plantation Tbk (GOLL). Lebih lanjut, sepanjang 2014 terdapat 1 perusahaan yang melakukan relisting, yaitu PT Tunas Alfin Tbk (TALF). Pada 2014, BEI juga telah melakukan delisting terhadap 1 Perusahaan Tercatat, yaitu PT Asia Natural Resources Tbk. (ASIA).

Sepanjang tahun 2015, IHSG mengalami penurunan sebesar $12,12 \%$ dibandingkan dengan posisi tahun sebelumnya. Pada tahun 2015 para investor IHSG melakukan net jual mencapai 22,6 triliun, sebagai perbandingan untuk sepanjang tahun 2014 para investor melakukan net beli mencapai 42,6 triliun.

Penurunan IHSG ini disebabkan beberapa hal baik dari sisi internal maupun sisi eksternal. Dari sisi eksternal adalah masih berlanjutnya pelemahan dan ketidakpastian perkembangan ekonomi global. Realisasi pertumbuhan Amerika Serikat yang belum sesuai dengan ekpekstasi banyak pihak sehingga kebijakan normalisasi suku bunga menjadi tidak pasti. Disamping itu, kebijakan ekonomi di Eropa dan Jepang yang mempertahankan kebijakan suku bunga rendah turut menambah likuiditas global yang mengarah kepada semakin banyaknya danadana yang beralih ke pasar Amerika Serikat. Ke$d u a$, penguatan mata uang USD terhadap hampir seluruh mata uang dunia. Membaiknya fundamental AS, sedang pada saat yang sama terjadi pelemahan ekonomi China, memicu ekspektasi positif investor yang mencari return yang lebih tinggi. Ketiga, pelemahan harga komoditas internasional disebabkan perlambatan ekonomi global, ditunjang lagi oleh penguatan USD melalui mahalnya harga impor.

Ketidakpastian kondisi global tersebut, disertai oleh pelemahan kinerja perekonomian Indonesia sehingga tekanan di pasar keuangan turut meningkat. Indikasi tekanan pada ekonomi Indonesia tercermin pada beberapa variabel ekonomi, diantaranya: meningkatnya bunga Surat Berharga Negara 10 tahun dari $7.74 \%$ pada semester I 2014 menjadi $8.26 \%$ pada semester I 2015. Perlambatan intermediasi perbankan tercermin dari Loan to Deposit Ratio, $89.30 \%$ pada semester II 2014 menjadi $88.62 \%$ pada semester I 2015 yang dipicu oleh meningkatnya resiko perbankan, tercermin dari resiko kredit, pasar, dan likuiditas. Kenaikan kredit macet perbankan menjadi $2.56 \%$ pada semester I 2015 dari $2.16 \%$ di semester I 2014, termasuk pada sektor usaha kecil menengah. Tekanan pada sektor rumah tangga meningkat ditandai dengan rasio hutang terhadap pendapatan di atas $30 \%$. Nilai tukar Rupiah melemah 9.8\% antara Desember 2014 hingga Desember 2015. BI rate masih di tingkat $7.5 \%$ per Desember 2015 atau turun 25 basis poin dibanding Desember 2014. Cadangan devisa menurun sebesar $10.4 \%$ per Desember 2015, dibanding Desember 2014. Tekanan inflasi menurun drastis menjadi $4.89 \%$ per November 2015 dibanding Desember 2014, sebesar 8.36\% dan peningkatan volume hutang luar negeri sebesar 3.5\% per Oktober 2015 dibanding Desember 2014, dimana didominasi oleh utang sektor swasta.

Dengan didukung data-data diatas maka, kita dapat menarik kesimpulan jika sektor perekonomian sedang membaik tingkat pengembalian di LQ45 lebih menguntungkan dibanding 
di JII. Perhitungan menggunakan indeks Sharpe, Treynor dan Alpha Jensen menunjukkan nilai yang didapat di LQ45 lebih tinggi dibandingkan JII pada tahun 2014.

Berbeda dengan tahun 2014, pada tahun 2015 ke-3 indeks perhitungan, Indeks Sharpe, Treynor, dan Alpha Jensen, menunjukkan nilai yang lebih tinggi dibandingkan pada indeks JII dibandingkan indeks LQ45. Hal ini menunjukkan bahwa pada perekonomian yang sedang menurun berinvestasi pada indek JII lebih menguntungkan dibandingkan indeks LQ45.

Untuk penghitungan gabungan tahun 20142015, hasil yang didapat lebih bervariasi dimana indeks Alpha Jensen dan Sharpe lebih tinggi pada indeks LQ45 namun pada indeks Treynor nilai lebih tinggi pada indeks JII. Pada penghitungan indeks alpha Jensen, selain memasukkan suku bunga bank Indonesia namun juga memasukan rata-rata return pasar sebagai perbandingan. Berdasarkan penghitungan Alpha Jensen, berinvestasi di indeks LQ45 kurang menguntungkan karena risiko yang lebih tinggi dibanding return yang didapat dibandingkan rata-rata return pasar.

\section{SIMPULAN}

\section{Kesimpulan}

Beberapa kesimpulan yang dapat diambil dari penilitian ini adalah:

1. Kinerja LQ45 pada tahun 2014-2015 lebih baik dibandingkan JII jika menggunakan metode Sharpe. Untuk tahun 2014 indeks LQ45 lebih baik dibanding JII dan tahun2015 dimana indeks JII lebih baik dibandingkan LQ45.

2. Kinerja JII pada tahun 2014-2015 lebih baik dibandingkan JII jika menggunakan metode Treynor. Untuk tahun 2014 hasilnya LQ45 lebih baik dibandingkan JII. Untuk tahun 2015, indeks JII lebih baik dibandingkan LQ45.

3. Untuk tahun 2014-2015, dengan menggunakan perhitungan indeks Alpha Jensen hasilnya lebih menguntungkan berinvestasi di JII dibandingkan di LQ45. Sedang untuk tahun 2014, lebih menguntungkan berinvestasi di LQ45 dan untuk 2015, lebih menguntungkan berinvestasi di indeks JII.

\section{Saran}

1. Saran untuk Bursa Efek Indonesia

Dengan hasil yang didapat dari penelitian ini, Bursa efek Indonesia diharapkan bisa menambah jumlah saham-saham syariah yang masuk ke dalam bursa efek. Hal ini mengingat sebagian besar penduduk Indonesia adalah beragama Islam yang mana hal tersebut akan menarik investor-investor baru untuk berinvestasi di bursa saham.

2. Saran untuk Investor

Untuk para investor, dengan menggunakan 3 metode penghitungan kinerja saham yang berbeda hal ini dapat menjadi referensi dengan metode pemilihan apa yang akan digunakan dalam menentukan pilihan sahamnya. Metode Sharpe, Treynor, dan Alpha Jensen memiliki kelebihan dan kelemahannya masing-masing.

3. Saran untuk Peneliti Selanjutnya

Untuk penelitian selanjutnya sebaiknya jangka waktu penelitian lebih panjang untuk mendapatkan hasil yang komprehensif. Hal menarik lainnya untuk penelitian selanjutnya adalah fenomena meningkatnya bursa saham dan hubungannya dengan tahun politik pemilihan DPR dan Presiden. Pada penelitian ini ditemukakan bahwa selama terjadi tahun politik pemilihan Presiden dan DPR bursa saham akan meningkat secara signifikan.

\section{Implikasi Manajerial}

Dengan diterapkannya metode penghitungan kinerja Sharpe, Treynor, dan Alpha Jensen maka investor dapat menentukan pilihan sahamnya dengan mempertimbangkan keuntungan dan risikonya. Kesulitan yang dihadapi investor selama ini adalah bagaimana mengukur risiko secara akurat, banyak pertimbangan yang perlu diperhitungkan baik faktor risiko internal ataupun faktor risiko eksternal.

\section{DAFTAR PUSTAKA}

\section{Buku-Buku}

Ang, Robert. 2001. Buku Pintar Pasar Modal Indonesia. Mediasoft.com

Brigham, Eugene F., and Joel F. Houston. 2001. Manajemen Keuangan. Buku 1 edisi 8. Penerbit Erlangga. Jakarta.

Gallagher, T. J., dan J. D. Andrew. 2007. Financial Management, Principles \& Practice, $4^{\text {th }}$ ed., Saint Paul: Freeload Press, Inc.

Ghozali, Imam. 2011. Aplikasi Analisis Multivariate dengan Program IBM SPSS 19-5/E. Universitas Diponegoro. Semarang.

Hartono. 2010. SPSS 16.0 Analisis Data Statistik dan Penelitian Edisi-2. Pustaka Pelajar. Yogyakarta.

H.M Jogiyanto. 2000. Teori portofolio dan Analisis Investasi, Edisi kelima. BPFE. Yogyakarta.

Husein, Umar. 2005. Metode Penelitian. Salemba Empat. Jakarta.

Kuncoro, Mudrajad. 2009. Metode Riset untuk Bisnis \& Ekonomi Edisi 3. Penerbit Erlangga. Jakarta.

Melewar, T.C. ed., 2008. Facets of corporate identity, 
communication and reputation. Routledge.

MIFC 2014. Malaysia International Islamic Financial centre, Kuala Lumpur, Malaysia.

OJK, 2015, StatistikSaham November 2015 melalui http://www.ojk.go.id/id/data-dan-statistik/ default.aspx

Prasetyo, Bambang, and Lina MiftahulJannah. 2005, Metode Penelitian Kuantitatif: teori dan aplikasi. PT Raja GrafindiPersada. Jakarta.

Besley, S. and Brigham, E.F., 2008. Essentials of managerial finance. Thomson SouthWestern.

WIR. 2015, World Investment Report 2015 - United Nation Conference on Trade and Development, Geneva, UNCTAD

Zubir, Zalmi. 2011. Manajemen Portofolio (Penerapannya dalam Investasi Saham). Salemba Empat. Jakarta.

\section{Jurnal}

Albaity, Mohamed, and Rubi Ahmad. 2008. "Performance of Syariah and composite indices: Evidence from Bursa Malaysia." Asian Academy of Management Journal of Accounting and Finance 4.1 (2008): 23-43.

Antonio, Muhammad Syafii, HafidhohHafidhoh, and HilmanFauzi. 2013. "the islamic capital market volatility: a comparative study between in Indonesia and malaysia." Buletin Ekonomi Moneter dan Perbankan 15.4 (2013): 377400.

Desiana, Lidia, and Isnurhadi Isnurhadi. 2003. "Perbandingan Kinerja Reksa Dana Saham Konvensional dengan Reksa Dana Saham Syariah Di Bursa Efek Indonesia." Jurnal Manajemen dan Bisnis Sriwijaya 10.20 (2012): 81-98.

Esha, MulyaRiyady, Mohamad Heykal, and Titik Indrawati. "Analisis Perbandingan Reksa Dana Saham Syariah Dengan Reksa Dana Saham Konvensional Periode 2009-2012."

Farida. T. Rachmayanti. 2003."Analisis kinerja portofolio saham syariah pada bursa efek Jakarta tahun 2001-02."

Graham John, R., B. Smart Scott, and L. Megginson William. 2010. "Corporate Finance-Linking Theory to What Companies Do."

Hanafi, Mamduh M., and Syafiq M. Hanafi. 2012. "Perbandingan Kinerja Investasi Syariah Dan Konvensional: StudiPada Jakarta Islamic Index (JII) Dan Indeks LQ45. "Jurnal Ekonomi dan Bisnis Islam| Vol. VII 17 (2012).

Irfan Syauqi Beik et.al. 2011. "Pengaruh Indeks Harga Saham Syariah Internasional Dan Variabel Makro Ekonomi Terhadap Jakarta Islamic Index. " Al-Iqtishad: Journal of Islamic Economics 6.2 (2014): 155-178.

Isnurhadi, Isnurhadi. 2014. "Analisis Model Capm
Dalam Memprediksi Tingkat Return Saham Syariah Dan Konvensional (StudikasusSaham di Bursa Efek Indonesia)." Jurnal Ilmiah Manajemen Bisnis dan Terapan 11.1 (2014): 19-31.

Jensen, Michael. 1968. "The performance of mutual funds in the period 1945-1964." The Journal of finance 23.2 (1968): 389-416.

Khaled A. Hussein (2005). "Ethical investment revisited: evidence from Dow Jones Islamic indexes." The Journal of Investing 14.3 (2005): 105-126.

Madyan, M., U. Salim, and M. Anshori. 2013. "Liquidity determinants of Sharia and Non Sharia stocks." IOSR Journal of Business and Management 9 (2013): 28-38.

Moazam Farooq dan Sjjad Zaheer. 2015. "Are Islamic Bank more resilient during financial panic". IMF Working Paper 2015.

Medhioub Imed dan Chaffai Mustafa. 2016. "Islamic versus conventional stock market indices synchronization". Academic Journals Africa Journal of Business and Management 270-278 2016.

Noviastuty, Ari. 2013."Evaluasi kinerja portofolio antara saham syariah dengan saham konvensional di bursa efek indonesia." Performance. Vol. 14. No. 2. 2013.

Prasetyo, Jeffry, and Ervita Safitri. 2014. Analisis Perbandingan Kinerja Reksadana Saham dengan Kinerja Pasar (IHSG) di Bursa Efek Indonesia.

Rahmawati. 2013. Studi Empirik Perbandingan Kinerja Antara Jakarta Islamic Index (JII) Dan Indeks LQ-45 Di Bursa Efek Indonesia Pada Saat, Sebelum, Dan Setelah Krisis Keuangan Global. Diss. Universitas Muhammadiyah Surakarta, 2013.

Syafrida, Ida, Indianik Aminah, and Bambang Waluyo. 2014. "Perbandingan Kinerja Instrumen Investasi Berbasis Syariah Dengan Konvensional Pada Pasar Modal Di Indonesia." Al-Iqtishad: Journal of Islamic Economics 6.2 (2014): 195-206.

Treynor, Jack L. 1965. "How to rate management of investment funds." Harvard business review 43.1 (1965): 63-75.

William F. 1966. "Mutual fund performance." The Journal of business 39.1 (1966): 119-138. 